\title{
Prediabetes: An Update and a Rational for Diagnostic Confusion
}

\section{Prediyabet: Tanısal Karmaşayı Engellemek İçin bir Güncelleme}

\author{
Okan Sefa Bakiner ${ }^{1}$,Emre Bozkırlı ${ }^{1}$, Aydan Aksöyek ${ }^{2}$, Akatlı Kürşad Özşahin ${ }^{2}$
}

\begin{abstract}
The aim of this review is to increase awareness for prediabetes and help diagnose maximum number of prediabetic patients with minimum number of tests for physicians and health care workers. Prediabetes is a significant health problem because it can cause microvascular and macrovascular complications, accompany metabolic syndrome and predict the development of diabetes. It is common worldwide; however, most patients cannot be diagnosed because single tests used for scanning it have low diagnostic value alone. In addition; different definitions released by different organizations increase the clinicians' concept of confusion. As a result; developing complications in initially undiagnosed patients call for greater efforts and costs. Therefore: an early and correct diagnosis of prediabetes is important. It is not rational to increase the number of tests for every case considering increased costs. According to this; classification of cases depending on risk status would be correct to assess the tests for scanning. The risk stratification is also discussed. Primary care physicians need to have a good understanding of screening for prediabetes as a core competency and to serve proactively.
\end{abstract}

Key words: Prediabetes, screening tests

\section{ÖZET}

Bu derlemenin amacı hekimlerin prediyabet farkındalığını artırmak ve en az sayıda test ile en fazla sayıda prediyabetik hastanın teşhis edilmesine yardımcı olmaktır. Prediyabet mikrovasküler ve makrovasküler komplikasyonlar oluşturması, metabolik sendroma eşlik etmesi ve diyabet gelişimini öngürdürmesi açısından önemli bir sağlık sorunudur. Dünyada oldukça yaygın olup tek bir testle tanısal değeri düşük olduğu için hastaların çoğu teşhis alamamaktadır. Ek olarak değişik çalışma gruplarının ortaya koyduğu değişik yaklaşımlar klinisyenlerin konsept karmaşasını artırmaktadır. Sonuç olarak erken dönemde teşhis edilememiş hastalarda gelişen komplikasyonlar daha fazla çaba ve maliyete sebep olur. Bu yüzden prediyabetin erken ve doğru teşhisi gereklidir. Maliyetler gözönüne alındığında prediyabet teşhisine yönelik her hasta için çok sayıda test istenmesi de akla yakın gözükmemektedir. Buna göre; tanı için gerekli testlerin belirlenmesinde vakaların sahip olduları risk durumuna göre sınıflandırılması doğru olacaktır. Risk belirlenmesi konu içinde tartışılmıştır. Birinci basamak hekimlerinin prediyabete yönelik yeterliliklerinin sağlanması koruyucu hekimlik hizmeti sunmalarının da önünü açacaktır.

Anahtar kelimeler: Prediyabet, tanısal testler

\footnotetext{
Received / Geliş tarihi: 18.04.2018 Accepted / Kabul tarihi: 28.09 .2018

${ }^{1}$ Baskent University Dep. of Endocrinology

${ }^{2}$ Baskent University Dep. of Family Medicine

*Address for Correspondence / Yazışma Adresi: Akatlı Kürşad Özşahin, Baskent University Dep. of Family Medicine Adana - TÜRKIYYE, E-mail: kozsahin@gmail.com
}

Bakiner OS, Bozkırlı E, Aksöyek A, Özşahin AK. Prediabetes: An Update and a Rational for Diagnostic Confusion. TJFMPC, 2019 ;13(1): 85-94. DOI: $10.21763 /$ tjfmpc.528045 


\section{Definition and Importance of Prediabetes}

Conditions, where blood glucose levels are higher than normal yet without reaching diabetes diagnostic limits, are called prediabetes. They are significant because blood glucose levels in prediabetes limits are associated with increased cardiovascular risk and total mortality. ${ }^{(1-2)}$

Results of population-based screening studies display that $1 / 3$ of diabetic patients are still undiagnosed. The mean delay on the diagnosis of diabetes is seven years and therefore most patients carry microvascular complications like retinopathy or nephropathy at the time of diagnosis. Besides prediabetes itself causes an increase in the risk of cardiovascular diseases. Possible complications in patients without timely diagnosis increase the costs for follow up and treatment; therefore the diagnosis of prediabetes is important as early diagnosis can mostly prevent these. ${ }^{(3)}$

Prediabetes Epidemiology: According to the National Diabetes Statistics Report published in $2014 ; 37 \%$ of the population in the USA is prediabetic. ${ }^{(4)}$ NHANES 2005-2006 data shows that $34,6 \%$ of the population is prediabetic, with $19,6 \%$ impaired fasting glucose (IFG), 5,4\% impaired glucose tolerance (IGT) and 9,8\% combination of both. ${ }^{(5)}$ In 2015 IDF diabetes atlas; impaired glucose tolerance worldwide is $6,7 \%$ and 318 million people are estimated to be prediabetic which is predicted to reach 481 million by 2040. Prediabetes frequency increases with age ${ }^{(6)}$ According to 2002 data of TURDEP study which is one of the most comprehensive epidemiologic researches held in
Turkey, prediabetes prevalence was $6,7 \%$, and in TURDEP2 repeated ten years later was $30,4 \% .{ }^{(7-8)}$

Raise of prediabetes frequency in the World is associated with urbanization, increased vegetable oil consumption, sedentary lifestyle, changing nutrition habits towards high glycemic index and related obesity. Increased stress sources and ethnic effects may also be playing roles. ${ }^{(9)}$

The History of Prediabetes: Jackson has first used the term prediabetes in 1952 to emphasize the risk after pregnancy for women with gestational diabetes in British Medical Journal. The same researcher has defined prediabetes in 1952. In Sixties cases under risk for prediabetes have been defined. In 1979 National Diabetes Data Group (NDDG) has defined impaired glucose tolerance (IGT) and in 1997. American Diabetes Association (ADA) has defined impaired fasting glucose (IFG) and impaired glucose tolerance (IGT).ADA has used the term prediabetes for IFG and IGT since 2005.

Term prediabetes has not been fully accepted by all communities working on diabetes. WHO is using the term mild hyperglycemia and National Specialist Committee (Uzman Komitesi) is using the term high risk for development of diabetes. (11-12)

Prediabetes categories:

- Classification of prediabetes and historical development process are summarized in table 1.

Table 1. Prediabet categories according to Diabetes Guidelines and changes in historical definition process

\begin{tabular}{|l|l|l|l|l|l|}
\hline & ADA 1997 & ADA 2003 & WHO 2006 & ADA 2014 & $\begin{array}{l}\text { TEMD } \\
2014\end{array}$ \\
\hline $\begin{array}{l}\text { Impaired fasting glucose } \\
\text { (mg/dl) }\end{array}$ & $110-125$ & $100-125$ & $110-125$ & $100-125$ & $100-125$ \\
\hline $\begin{array}{l}\text { Impaired glucose tolerance } \\
(2 \mathrm{hr} \text { after OGTT-mg/dl) }\end{array}$ & $140-199$ & $140-199$ & $140-199$ & $140-199$ & $140-199$ \\
\hline $\begin{array}{l}\text { High risk group } \\
\text { HbA1C*\% }\end{array}$ & - & - & - & $5.7-6.4$ & $5.7-6.4$ \\
\hline
\end{tabular}

*Needs to be certified by National glycated hemoglobin standardization programs and be calibrated by HPLC (high-pressure liquid chromatography) used in DCCT (diabetes control and complications trial) OGTT: Oral glucose tolerance test, ADA: American Diabetes Association, WHO: World Health Organization, TEMD: Turkish Association of Endocrinology and Metabolism.

Striking differences in these definitions are; world health organization accepts cut off point for IFG as $110 \mathrm{mg} / \mathrm{dl}$ and for ADA and TEMD it is 100 $\mathrm{mg} / \mathrm{dl}$. Also according to World health organization measures of $\mathrm{HbA} 1 \mathrm{C}$ are not included in criteria for diagnosis but ADA and TEMD accept the limit values of $\mathrm{HbA} 1 \mathrm{C}$ as the high-risk group.

Major differences for IFG and IGT: IGT is rather associated with peripheral (skeletal muscle) insulin resistance whereas IFG is associated with increased gluconeogenesis. In combination form, there is extrahepatic and hepatic insulin resistance and increased gluconeogenesis. In IFG there is an isolated defect in first phase insulin secretion(early phase), and IGT is associated with both early phase and second phase insulin secretion defect. (13) IGT is closely connected with future diabetes progression. Association of IFG and IGT doubles the risk. IGT is more associated with an increase in cardiovascular risk and microvascular complications like retinopathy and neuropathy (14) 
Clinical significance of Prediabetes: Its association with given complications displays the clinical significance of diabetes. ${ }^{(15)}$

Table 2. Clinical significance of prediabetes
Progression to diabetes
Cardiovascular disease risk increase
Periodontal impairments
Cognitive dysfunction
Microvascular disease
Hypertension
Obstructive sleep apnea syndrome
Erectile dysfunction
Metabolic syndrome
Nonalcoholic fatty liver disease and steatohepatitis
Cancer

Therefore appropriate diagnosis of prediabetes is important for prevention and management of these complications. $70 \%$ of prediabetics end up with diabetes. It has been reported that annual progression to diabetes in the prediabetic population is $6-9 \%$ for IFG, $4-6 \%$ for IGF and $15-19 \%$ for an association of both. For HbA1C; values between 5.5-6 have 9-25\% and 6-6.5 have $25-50 \%$ risk for progression to diabetes for 5 years. $^{(16-17)}$
In the Whitehall study released in 2009; duration between the start of metabolic disorders and overt diabetes was shown to be 13 years and that no glycemic abnormalities were detected in blood 2-6 years before the onset of diabetes and also this duration is associated with increasing insulin resistance and prediabetes takes place towards the final period. ${ }^{(18)}$

Prediabetes and Metabolic Syndrome: The association of prediabetes with metabolic syndrome is well known. A study has shown that only $19 \%$ of metabolic syndrome cases have normal fasting glucose, $42 \%$ are IFG, $34 \%$ are IGT and $74 \%$ are the combination of both. ${ }^{(19)}$ Although the definitions of prediabetes and metabolic syndrome are closely associated they are accepted to be different entities superposing each other. Metabolic syndrome was defined as a lethal endocrinopathy which starts with insulin resistance, abdominal obesity, glucose intolerance and systemic disorders like diabetes mellitus, dyslipidemia, hypertension or coronary artery disease all linked which each other by TEMD in a metabolic syndrome guideline released in 2009 and also named it as insulin resistance syndrome.Various metabolic syndrome criteria developed by different groups are still commonly used NCEP-ATP III criteria.

\begin{tabular}{|l|l|}
\hline \multicolumn{2}{|l|}{ Table 3. NCEP ATP III metabolic syndrome diagnostic criteria } \\
\hline NCEP ATP III metabolic syndrome definition ( Presence of at least 3 criteria out of 5 is diagnostic) \\
\hline Risk Factor & Limit Value \\
\hline Waist circumference for men & \multicolumn{1}{c|}{$>102 \mathrm{~cm}$} \\
\hline Waist circumference for women & $>88 \mathrm{~cm}$ \\
\hline Plasma Tryglicerid levels & $>150 \mathrm{mg} / \mathrm{dl}$ \\
\hline HDL cholesterol for men & $<40 \mathrm{mg} / \mathrm{dl}$ \\
\hline HDL cholesterol for women & $<50 \mathrm{mg} / \mathrm{dl}$ \\
\hline Blood Pressure & $>130 / 85 \mathrm{mmHg}$ \\
\hline Fasting Plasma Glucose & $>110 \mathrm{mg} / \mathrm{dl}$ \\
\hline
\end{tabular}

WHO defines the presence of insülin resistance as the major finding for metabolic syndrome diagnosis

\section{Table 4. Metabolic Syndrome Criteria for WHO}

Insulin resistance defined with one of the below:

Type 2 Diabetes Mellitus

Impaired fasting glucose

Impaired glucose tolerance

In hyperinsulinemic euglycemic clamp study; uptake of insülin being less than the last quarter of the population

\section{At least two of the below with the previous condition:}

Use of antihypertensive drugs or presence of hypertension $(\geq 140 / 90 \mathrm{mmHg})$

Blood triglycerides $\geq 150 \mathrm{mg} / \mathrm{dl}$

HDL cholesterol $\leq 35 \mathrm{mg} / \mathrm{dl}$ in men and $\leq 40 \mathrm{mg} / \mathrm{dl}$ in women

Body Mass Index $>30 \mathrm{~kg} / \mathrm{m} 2$ and/or waist/hip ratio $>0.9$ for men and $>0.85$ for women

Urinary albumin excretion rate $<20 \mathrm{mcg} / \mathrm{min}$. or urinary albumin/ creatinine ratio $\geq 30 \mathrm{mg} / \mathrm{g}$

Despite this IDF accepts the presence of central obesity for diagnosis of metabolic syndrome in the first hand. 


\begin{tabular}{|c|c|}
\hline \multicolumn{2}{|c|}{$\begin{array}{l}\text { Central Obesity(waist circumference values over ethnic-specific limits or body mass index }>30 \mathrm{~kg} / \mathrm{m} 2 \\
+ \text { at least two of the below }\end{array}$} \\
\hline Elevated tryglicerid levels & $\begin{array}{l}\geq 150 \mathrm{mg} / \mathrm{dl} \\
\text { Or specific medication for his lipid anomaly }\end{array}$ \\
\hline Low HDL cholesterol & $\begin{array}{l}<40 \mathrm{mg} / \mathrm{dl} \text { for men } \\
<50 \mathrm{mg} / \mathrm{dl} \text { for women } \\
\text { Or specific medication for his lipid anomaly }\end{array}$ \\
\hline High blood pressure & $\begin{array}{l}\text { Systolic BP } \geq 150 \text { or diastolicBP } \geq 85 \mathrm{mmHg} \text { or } \\
\text { antihypertensive medication }\end{array}$ \\
\hline High fastening blood glucose & $\mathrm{FBG} \geq 100 \mathrm{mg} / \mathrm{dl}$ or diagnosed type 2 diabetes \\
\hline
\end{tabular}

American Association of Clinical Endocrinologists prefers the term insulin resistance syndrome over metabolic syndrome and defines the disease is somehow a more detailed fashion.

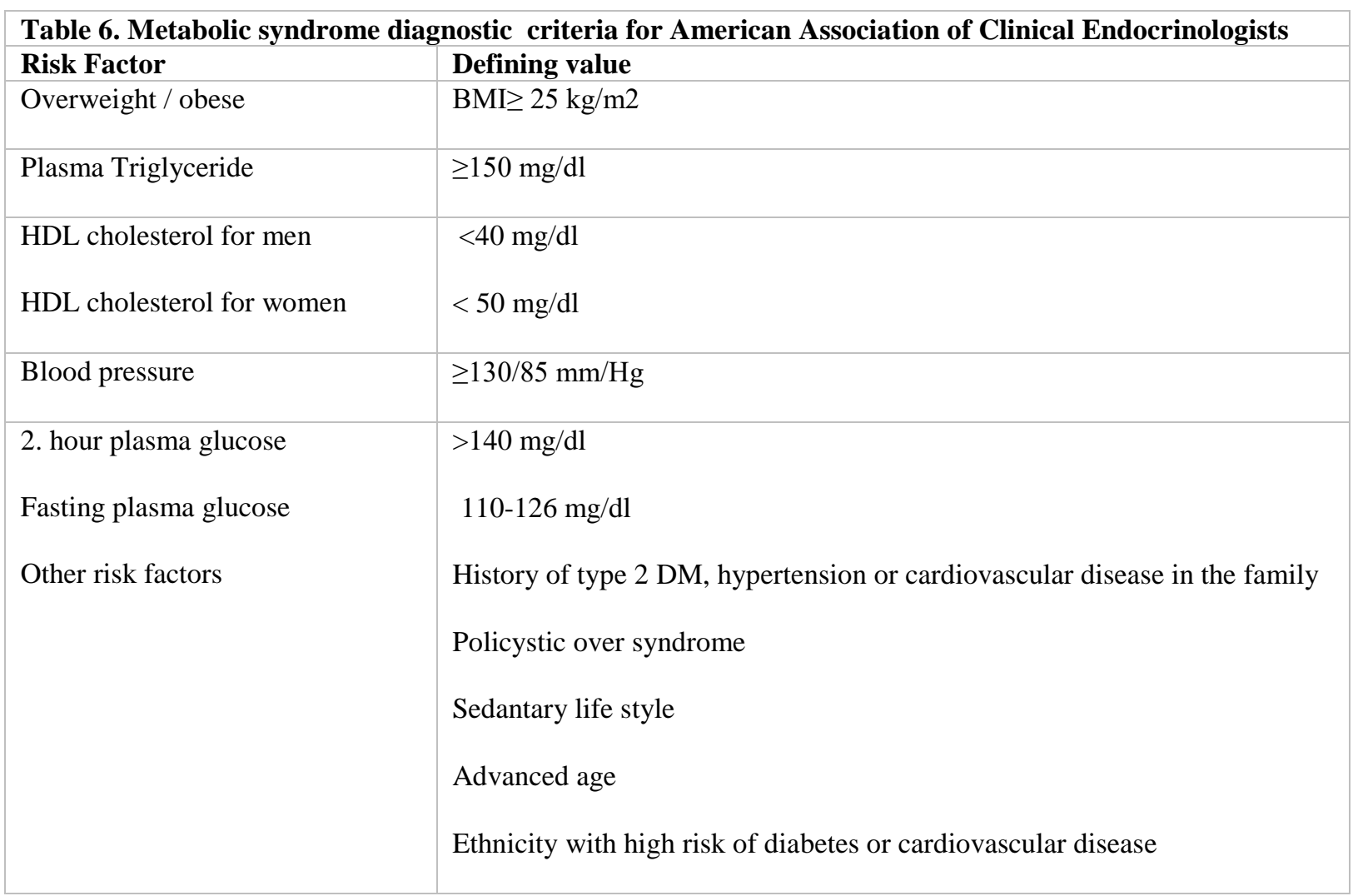

Different definitions and various diagnostic criteria for metabolic syndrome by different groups not only have been confusing the clinicians but also don't carry similarities for defining the cardiovascular risk. For example; a survival analysis has shown that NCEP diagnostic criteria are more parallel to coronary heart disease than IDF diagnostic criteria. ${ }^{(20)}$ Another study has shown that predicting future diabetes with IDF criteria is more sensitive consecutively from ATP III, WHO diagnostic criteria, impaired glucose tolerance, impaired fasting glucose, and that increased sensitivity is associated with increased false positive results. ${ }^{(21)}$ Diabetes prevention program showed that metformin therapy in metabolic syndrome patients has little effect compared to lifestyle changes to regulate metabolic syndrome; which indirectly is a proof for prediabetes and metabolic syndrome be different. ${ }^{(22)}$ It can be concluded that insulin resistance is a starting point both for prediabetes and metabolic syndrome, that prediabetics have $75 \%$ metabolic syndrome accompanying insülin resistance, that prediabetes, and metabolic syndrome are each associated with increased cardiovascular risk and prediabetes predicts future diabetes. ${ }^{(23)}$ According to this prediabetes and metabolic syndrome are. According to this prediabetes and metabolic syndrome are close but different entities. Some sources use insulin resistance syndrome and metabolic syndrome as equivalent definitions.

Prediabetes and vascular complications: Many studies have shown that prediabetes is 
associated with cardiovascular disease development. In GAMI study $35 \%$ of patients with acute myocardial infarction were prediabetic and in Euro ve China study the frequency of prediabetes in coronary events was 37\%.(24) Another important epidemiologic study has shown that there is a close association between prediabetes and heart failure and related morbidity. ${ }^{(25)}$

Clinical studies have shown the association of prediabetes with microvascular complications besides cardiovascular risk. In IFG cases micro and macroalbuminuria is frequent when compared to normoglycemics, and according to 1999-2006 NHANES data $17,7 \%$ of chronic renal failure patients are prediabetic and $10,6 \%$ are normoglycemic. ${ }^{(26-27)}$

The incidence of diabetic retinopathy in the prediabetic group was found to be $7.9 \%$ in DPP study. (28) Another study reported an increased incidence for retinopathy which is correlated to the fasting blood glucose even at prediabetes levels. ${ }^{(29)}$ There are a few studies showing the association of increased polyneuropathy risk and development of dementia with prediabetes. ${ }^{(30-31)}$

\section{Which test is more valuable for diagnosing prediabetes?}

It has been shown that elevated fasting blood glucose levels even if they are still in normal limits may predict future diabetes. ${ }^{(32)}$ A metaanalysis released in 2010 which included 102 clinical studies showed a clear association between fasting blood glucose levels and cardiovascular events. ${ }^{(33)}$ Besides, the association between impaired fasting blood glucose levels and raising mortality in coronary heart failure patients has been revealed. ${ }^{(34)}$ Apart from future diabetes risk and increased cardiovascular risk, impaired fasting glucose has possible links with microvascular events. In a similar study undertaken in three different nations, similar levels of impaired fasting glucose is closely associated with retinopathy risk. ${ }^{(35)} \mathrm{ADA}$ has dropped the value of fastening blood glucose levels from $110 \mathrm{mg} / \mathrm{dl}$ to $100 \mathrm{mg} / \mathrm{dl}$ and this was accepted by many organizations but was not accepted by WHO because it caused a serious increase in the population at risk to screen and that low $\mathrm{HbA} 1 \mathrm{C}$ and normal postprandial glucose levels did not reflect the cardiovascular risk. ${ }^{(36)}$

Although HbA1C levels have lately been added to diagnostic criteria of prediabetes, its diagnostic value is assumed to be high because individual variability is so small, and displaying different results in the same people at different times and differences reaching as high as $12-17 \%$ for fasting blood glucose and OGTT assessments. ${ }^{(37)}$
The disadvantages of this test are that it is affected by many clinical conditions (Table 6) and it has low sensitivity to diagnose prediabetes compared to fasting blood glucose and. OGTT. When 1988-2006 NHANES studies are adopted to HbA1Ccriteria, 1/3 of prediabetics could not be diagnosed. ${ }^{(38)}$ Various clinical studies have shown that when HbA1C is compared to gold standard OGTT; the sensitivity for diagnosing prediabetes is between $16,7 \%$ and $59 \%$ specificity $92 \%$. When $\mathrm{HbA} 1 \mathrm{C}$ cut off value was taken lower to increase sensitivity, the ratio of false positivity was observed to increase similarly. (39) TURDEP2 study accomplished in Turkey has shown that FPG and 2nd-hour plasma glucose during OGTT together had $30.4 \%$ prevalence for prediabetes but HbA1C alone had a prevalence of $26.4 \%$ which is another proof for low sensitivity.

Studies have shown that postprandial glucose levels predict the cardiovascular events and cardiovascular mortality better than fastening blood glucose and HbA1C. ${ }^{(40-41)}$

Second-hour postprandial glucose measurements are shown to identify prediabetes better than those combined with fasting blood glucose. TURDEP study was released in Turkey in 2002, and on basis of OGTT prediabetes prevalence was $7,2 \%$ whereas in a local study in which OGTT and fastening blood glucose measurements were considered together it was $11,6 \% .^{(7-8-42)}$

Advantages and disadvantages of fastening blood glucose used in diagnosis, venous blood glucose levels after 2 hours of 75 gr oral glucose load and levels of $\mathrm{HbA} 1 \mathrm{C}$ are given in table 7.

Today 2-hour venous plasma glucose levels after $75 \mathrm{mg}$. oral glucose load is widely used as a diagnostic test however late studies show that firsthour plasma glucose levels can more effectively predict future diabetes. $\left({ }^{14)} \mathrm{A}\right.$ study released in 2009 displayed that if cases who had glucose levels > $155 \mathrm{mg} / \mathrm{dl}$ after one hour OGTT had accompanying metabolic syndrome; they had a greater chance of developing diabetes in 8 years follow up. ${ }^{(43)}$ Still there is no clear evidence to include glucose levels after 1 hour OGTT into a routine screening.

A meta-analysis of Stephan $\mathrm{N}$ et. al has specified that the presence of insülin secretion deficiency, insülin resistance, visceral obesity, and nonalcoholic fatty liver disease accelerates the development of prediabetes to diabetes. ${ }^{(44)}$ Ethnicity, previous gestational diabetes, history of polycystic over syndrome were also included in this risk group by another researcher. ${ }^{(45)}$ Such individuals display more progression to diabetes when they lose similar amounts of weight compared to risk-free individuals. Screening methods of today show a $50 \%$ accuracy of diagnosing prediabetes. ${ }^{(46)}$ Combined tests to improve the diagnostic value for prediabetes are considered and from lowest prognostic value to highest are OGTT-APG, OGTT-HbA1C, APG- 
HbA1C and APG-OGTT-HbA1C. ${ }^{(47)}$ AACE and American College of Endocrinology have underlined that $\mathrm{HbA} 1 \mathrm{c}$ be used for prediabetes screening only and for those who have prediabetic values. ${ }^{(48)}$ TEMD has used APG and OGTT for diagnosis of İsolated IFG, IFG; Isolated IGT, or combination of both.(49)

\section{Rational Approach for Prediabetes Diagnosis}

The first priority for prediabetes screening is to catch the greatest number of patients and managing the best risk prediction with the lowest screening costs Therefore an effective prediabetes screening calls for an assessment of patients belonging to high-risk group.

It is acceptable to accept patients over 40 years or patients with BMI $\geq 25 \mathrm{~kg} / \mathrm{m} 2$ as under high risk if they belong to one of the risk groups listed below.

\begin{tabular}{l}
\hline Table 7. Disadvantages of HbA1C for prognosing prediabetes \\
$\begin{array}{l}\text { Necessity of a Standardized Screening High Cost } \\
\text { Unavailability for some institutions } \\
\text { Variability upon ethnicity }\end{array}$ \\
\begin{tabular}{|l|l|}
\hline Medical interactions & $\begin{array}{l}\text { Hemoglobinopathies } \downarrow \\
\text { Short erythrocyte lifespan } \downarrow \\
\text { Acute blood loss/transfusion } \downarrow \\
\text { Pregnancy } \downarrow\end{array}$ \\
Iron deficiency anemia $\uparrow$ \\
uremia $\uparrow$ \\
hyper-triglyceridemia $\uparrow$ \\
alcohol addiction $\uparrow$
\end{tabular} \\
\hline Having low sensitivity compared to fastening blood glucose and OGTT \\
\hline
\end{tabular}

Table 8. The comparison of advantages and disadvantages of tests used for prediabetes diagnosis.

\begin{tabular}{|c|c|c|}
\hline Test & Advantage & Dysadvantage \\
\hline $\begin{array}{l}\text { Fasting blood } \\
\text { glucose }\end{array}$ & $\begin{array}{l}\text { Low cost } \\
\text { Improves diagnostic value when added to } \\
\text { other tests }\end{array}$ & Low diagnostic value and risk prediction alone \\
\hline $\begin{array}{l}\text { OGTT.2.hr } \\
\text { blood glucose }\end{array}$ & High-risk prediction value & $\begin{array}{l}\text { Hard to accomplish } \\
\text { Low sensitivity }\end{array}$ \\
\hline $\mathrm{HbA1C}$ & $\begin{array}{l}\text { No fastening needed } \\
\text { Low individual variability } \\
\text { High spesifity }\end{array}$ & $\begin{array}{l}\text { Expensive } \\
\text { Testability is high } \\
\text { Not standardized } \\
\text { Low sensitivity }\end{array}$ \\
\hline
\end{tabular}

Table 9. Risk factors (Adapted from TEMD 2016 diabetes screening and treatment guide)(49)

1. Those who have a first or second-degree relative with diabetes

2. Those who belong to a high-risk diabetes ethnicity

3. Women with previous history of gestational diabetes

4. Hypertensive individuals (blood pressure: $\mathrm{BP} \geq 140 / 90 \mathrm{mmHg}$ )

5. Dyslipidemic (HDL-cholesterol $\leq 35 \mathrm{mg} / \mathrm{dl}$ or triglyceride $\geq 250 \mathrm{mg} / \mathrm{dl}$ )

6. Polycystic over syndrome (PCOS) olan

7. Those who have clinical disease or findings related to insülin resistance (acanthosis nigricans)

8. Those who have coronary, peripheric or cerebrovascular disease

9. Those with low birth weight

10. Those with a sedentary lifestyle or with low physical activity

11. Those who consume saturated or low fiber

12. Schizophrenic patients and those who take atypic antipsychotics

13.Those with solid organ transplantation (especially renal) 
Management through different approaches for high risk or non-high risk individuals is suitable. Firstly cases must be differentiated as high-risk or non high risk. For high-risk cases, FPG and simultaneous OGTT with 2 hour glucose monitorization are advised.



Figure 1. Diagnostic approach for non high risk patients is advised according to the following algorithm

Standardized methods are needed for HbA1C levels. They need to be certificated by the National glycated hemoglobin standardization program and be calibrated according to highpressure liquid chromatography technique used in DCCT. Besides medical conditions given in table 6 that may affect level must not be present. It may lead to screening purposes using $\mathrm{HbA} 1 \mathrm{C}$ alone may cause skipping patients due to low sensitivity. High specificity and cost of this test make it a valuable confirmative tool. It can be used when high values are present at low-risk patients or low values are present at high-risk patients. Values between \%5.76.4 present higher risk.

\section{CONCLUSION}

Prediabetes is important due to clinical problems it causes and its ability to predict type 2 diabetes development. Although it is common worldwide half of the patients are left undiagnosed. We believe this is because the tests used for screening don't carry diagnostic power alone. It is also not rational to add many tests for screening which increases costs. 
Therefore an aggressive approach after identifying high-risk individuals would be appropriate. It is not yet clear which tests are needed to be combined for this group of patients. In this article, we suggest a diagnostic algorithm after discussing the advantages and disadvantages of present tests. We believe in the long run greater number of patients can be diagnosed with acceptable costs after confusion on this issue is revealed by way of new studies.

\section{REFERENCES}

1. Seshasai SR, Kaptoge S, Thompson A, et al, for the Emerging Risk Factors Collaboration. Diabetes mellitus, fasting glucose, and risk of cause-specifi c death. $\mathrm{N}$ Engl $\mathrm{J}$ Med 2011;364(9), 829-841

2. Balkau B. The DECODE study. Diabetes epidemiology: collaborative analysis of diagnostic criteria in Europe. Diabetes Metab. 2000 Sep;26(4):282-6.

3. American Diabetes Association Screening for type 2 diabetes. Diabetes Care 2004;27 Suppl 1: 11-14.

4. CDC national diabetes statistics report 2014 available in http//www.cdc.gov/diabetes/pubs/statsreport14 /national-diabetes-report-web.pdf -accessed september 42017

5. Karve A, Hayvard RA. Prevalence, diagnosis, and treatment of impaired fasting glucose and impaired glucose tolerance in nondiabetic U.S. adultsDiabetes Care 2010:33; p:2355-2359

6. www.idf.org/idf-diabetes-atlas-seventhedition-2015 - accessed september 42017

7. Satman I, Yilmaz T, Sengül A et al..Populationbased study of diabetes and risk characteristics in Turkey: results of the turkish diabetes epidemiology study (TURDEP)Diabetes Care2002;25:1551-6

8. Satman I, Omer B, Tutuncu Y, Kalaca S, Gedik S, Dinccag N, Karsidag K, Genc S, Telci A, Canbaz B, Turker F, Yilmaz T, Cakir B, Tuomilehto J; TURDEP-II Study Group.Twelve-year trends in the prevalence and risk factors of diabetes and prediabetes in Turkish adults. Eur J Epidemiol. 2013 Feb;28(2):169-80.

9. Lam DW, LeRoith D. The worldwide diabetes epidemic. Curr Opin Endocrinol Diabetes Obes 2012;19:93-6.

10. American Diabetes Association. Standards of medical care in diabetes.Diabetes Care 2005 Jan; 28(suppl 1): s4-s36

11. World Health Organization, International DF. Definition and diagnosis of diabetes mellitus and intermediate hyperglycaemia: report of a
WHO/IDF consultation. Geneva: World Health Organization; 2006. P: 127-128

12. International Expert Committee.International Expert Committee report on the role of the A1C assay in the diagnosis of diabetes. Diabetes Care. 2009; 32:1327-34

13. Faerch K, Borch-Johnsen K, Holst JJ, Vaag A. Pathophysiology and aetiology of impaired fasting glycaemia and impaired glucose tolerance: does it matter for prevention and treatment of type 2 diabetes?Diabetologia. 2009 Sep;52(9):1714-23

14. Abdul-Ghani M, DeFronzo RA, Jayyousi A.Prediabetes and risk of diabetes and associated complications: impaired fasting glucose versus impaired glucose tolerance: does it matter? Curr Opin Clin Nutr Metab Care 2016, 19:394-399.

15. Buysschaert M, Medina JL, Bergman M, Shah A, Lonier J.Prediabetes and associated disorders. Endocrine (2015) 48:371-393

16. Gerstein HC, Santaguida P, Raina Pet al.Annual incidence and relative risk of diabetes in people with various categories of dysglycemia: a systematic overview and meta-analysis of prospective studies. Diabetes Res Clin Pract 2007;78(3):305-12.

17. Zhang X. Gregg EW, Williamson DFet al. A1C level and future risk of diabetes: a systematic review.Diabetes Care2010;33:1665-73.

18. Tabak AG. Jokela M, Akbaraly $\mathrm{TN}$ et al.Trajectories of glycaemia, insulin sensitivity, and insulin secretion before diagnosis of type 2 diabetes: an analysis from the Whitehall II study.Lancet. 2009; 373:2215-21.

19. Grundy SM. Pre-diabetes, metabolic syndrome, and cardiovascular risk.J Am Coll Cardiol. 2012;59(7):635-643

20. Tong PC, Kong AP, So WY et al.The usefulness of the International Diabetes Federation and the National Cholesterol Education Program's Adult Treatment Panel III definitions of the metabolic syndrome in predicting coronary heart disease in subjects with type 2 diabetes.Diabetes Care 2007 May; 30(5): 12061211

21. Lorenzo C, Williams K, Hunt KJ, Haffner SM.The National Cholesterol Education Program - Adult Treatment Panel III, International Diabetes Federation, and World Health Organization definitions of the metabolic syndrome as predictors of incident cardiovascular disease and diabetes.Diabetes Care 2007 Jan; 30(1): 8-13

22. Goldberg RD, Mather K.Targeting the consequences of the metabolic syndrome in the Diabetes Prevention Program.Arterioscler Thromb Vasc Biol. 2012 September ; 32(9): 2077-2090 
23. Grundy SM.Metabolic syndrome: connecting and reconciling cardiovascular and diabetes worlds.J Am Coll Cardiol. 2006;47(6):10931100

24. Anselmino M,Mellbin L, Wallander M, Rydén L.Early detection and integrated management of dysglycemia in cardiovascular disease: a key factor for decreasing the likelihood of future events.Rev Cardiovasc Med.2008;9:29-38

25. Kristensen SL, Preiss D, Jhund PS, Squire Iet al. Risk Related to Pre-Diabetes Mellitus and Diabetes Mellitus in Heart Failure With Reduced Ejection Fraction: Insights From Prospective Comparison of ARNI With ACEI to Determine Impact on Global Mortality and Morbidity in Heart Failure Trial.Circ Heart Fail. 2016;Jan;9(1). pii: e002560 p: 87-93

26. Bianchi C, Miccoli R, Bonadonna RC, et al. Metabolic syndrome in subjects at high risk for type 2 diabetes: the genetic, physiopathology and evolution of type 2 diabetes (GENFIEV) study. Nutr Metab Cardiovasc Dis 2011;21:699-705.

27. Platinga LC, Crews DC, Coresh J, et al.Prevalence of chronic kidney disease in US adults with undiagnosed diabetes or prediabetes. Clin J Am Soc Nephrol.2010;5:673-682

28. DPP Res Group. The prevalence of retinopathy in impaired glucose tolerance and recent-onset diabetes in the Diabetes Prevention Program.Diabet Med.24;2:137-144

29. Wong TY,Liew G, Tapp RJ et al. Relation between fasting glucose and retinopathy for diagnosis of diabetes: three population-based cross-sectional studies.Lancet 2008;371:736743

30. Ziegler D, Rathmann W, Dickhaus T, Meisinger C, Mielck A; KORA Study Group.Neuropathic pain in diabetes, prediabetes and normal glucose tolerance: the MONICA/KORA Augsburg Surveys S2 and S3.Pain Med. 2009 Mar;10(2):393-400.

31. Weili $\mathrm{Xu}$, Caracciolo $\mathrm{B}$, Wang $\mathrm{HX}$ et al.Accelerated progression from mild cognitive impairment to dementia in people with diabetes. Diabetes 2010;59:2928-2935

32. Nichols G, Hillier TA, Brown JB. Normal fasting plasma glucose and risk of type 2 diabetes diagnosis. The American Journal of Medicine. 2008;121:519-524

33. The Emerging Risk Factors Collaboration. Sarwar N, Gao P, Seshasai SR et al. Diabetes mellitus, fasting blood glucose concentration, and risk of vascular disease: a collaborative meta-analysis of 102 prospective studies.Lancet 2010; 375:2215-2222

34. Fisman EZ, Motro M, Tenenbaum A, et al.Impaired fasting glucose concentrations in nondiabetic patients with ischemic heart disease: a marker for a worse prognosis. Am Heart J 2001;141:485-490

35. Kersten S, Desvergne B, Wahli W. Roles of PPARs in health and disease.Nature 2000; 405:421-424

36. Faerch K, Witte DR, Tabák AGet al. Trajectories of cardiometabolic risk factors before diagnosis of three subtypes of type 2 diabetes: a post-hoc analysis of the longitudinal Whitehall II cohort study.Lancet Diabetes Endocrinol 2013; 1: 43-51

37. Saudek CD, Herman WH, Sacks DB.et al. A new look at screening and diagnosing diabetes mellitus.J Clin Endocrinol Metab. 2008;93:2447-2453

38. Cowe CC, Rust KF, Byrd-Holt DD et al.Prevalence of diabetes and high risk for diabetes using A1C criteria in the U.S. population in 1988-2006. Diabetes Care 2010;33:562-568

39. Van 't Riet E, Alssema M, Rijkelijkhuizen JM et al.Relationship between A1C and glucose levels in the general Dutch population: the new Hoorn study.Diabetes Care 2010-33:61-66,

40. De Vegt F, Dekker JM, Ruhé HG et al.Hyperglycaemia is associated with all-cause and cardiovascular mortality in the Hoorn population: the Hoorn Study Diabetologia. 1999;42:926-931

41. $M$ Tominaga, Eguchi $\mathrm{H}$, Manaka $\mathrm{H}$ et al.Impaired glucose tolerance is a risk factor for cardiovascular disease, but not impaired fasting glucose. The Funagata Diabetes Study. Diabetes Care 1999 Jun; 22(6): 920-924

42. Gokcel A, Ozsahin AK, Sezgin N et al. High prevalence of diabetes in Adana, a southern province of Turkey.Diabetes Care. 2003 Nov;26(11):3031-4

43. Abdul-Ghani MA,Lyssenko V, Tuomi T, DeFronzo RA, Groop L.Fasting versus postload plasma glucose concentration and the risk for future type 2 diabetes: results from the Botnia Study. Diabetes Care 2009; 32:281-286

44. Catherine M,Kenneth C. Prediabetes : A Worldwide Epidemic. Endocrinol Metab Clin N Am 2016; Volume 45, Issue 4,751-764

45. Balion CM, Raina PS, Gerstein $\mathrm{HC}$ et al.Reproducibility of impaired glucose tolerance (IGT) and impaired fasting glucose (IFG) classification: a systematic review.Clin Chem Lab Med 2007;45:1180-5

46. Okosun IS, Seale JP, Lyn R, Davis-Smith YM. Improving Detection of Prediabetes in Children and Adults: Using Combinations of Blood Glucose Tests.Front. Public Health, 2015;Nov 20;3:260

47. Handelsman Y,loomgarden ZT, Grunberger Get al. American association of clinical endocrinologists and american college of endocrinology - clinical practice guidelines for 
developing a diabetes mellitus comprehensive care plan - 2015.Endocr Pract. 2015 April ;

21(Suppl 1): 1-87 